\title{
Anatomic and histologic analysis of paca larynx (Cuniculus paca, Linnaeus 1766)
}

[Análise anatômica e histológica da laringe da paca (Cuniculus paca, Linnaeus 1766)]

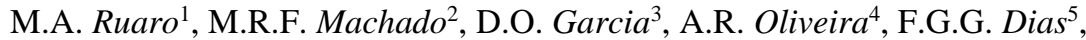 \\ S.P. Gomes ${ }^{6}$, L.M. Leal ${ }^{7}$, T.H.C. Sasahara ${ }^{6 *}$ \\ ${ }^{1}$ Aluno de graduação - Universidade Estadual Paulista - Jaboticabal, SP \\ ${ }^{2}$ Universidade Estadual Paulista - Jaboticabal, SP \\ ${ }^{3}$ Aluno de pós-graduação - Universidade de São Paulo - São Paulo, SP \\ ${ }^{4}$ Aluno de pós-graduação - Universidade de Franca - Franca, SP \\ ${ }^{5}$ Universidade de Franca - Franca, SP \\ ${ }^{6}$ Universidade de São Paulo - São Paulo, SP \\ ${ }^{7}$ Centro Universitário Ingá - Maringá, PR
}

\begin{abstract}
Paca (Cuniculus paca) has encouraged research as an experimental model both in the human medicine and veterinary, as well as the economic exploitation of its meat cuts, which favored its zootechnical use. There are no anatomical, microscopic descriptions and measurements of the larynx in this rodent. Eight pacas were dissected from the wild animal's sector of the Faculty of Agricultural and Veterinary Sciences of the University of the State of São Paulo. The larynx was observed located in the ventral region of the neck, ventral to the esophagus, connecting the pharynx to the trachea, with cylindrical and irregular shape. Laryngeal cartilages (epiglottic, thyroid, cricoid and arytenoid) are interconnected and have different shapes. Thyroid showed greater length and width, compared to the others. Laryngeal cartilages were submitted to histological processing and stained with hematoxylin-eosin and Masson's trichrome. The epiglottic cartilage was stained with toluidine blue. Laryngeal cartilages thyroid, cricoid and the lower portion of the arytenoids are of hyaline origin and, in contrast, the epiglottis and the upper portion of the arytenoids are elastic. This latter cartilage demonstrated taste buds. The results will be able to auxiliate in veterinary care and as well as the conservation programs for this rodent.
\end{abstract}

Keywords: laryngeal cartilages, morphology, wild rodent, respiratory system

\section{RESUMO}

A paca (Cuniculus paca) tem encorajado inúmeras pesquisas, tornando-a modelo experimental tanto em humanos como na veterinária, além da exploração econômica de seus cortes cárneos, que favoreceu diretamente sua importância zootécnica. Não há descrições anatômicas, microscópicas e mensurações da laringe desse roedor. Foram dissecadas oito laringes de pacas, provenientes do setor de Animais Silvestres da Faculdade de Ciências Agrárias e Veterinárias - Universidade Estadual Paulista. Observou-se que a laringe localiza-se na região ventral do pescoço, ventral ao esôfago, conectando a faringe à traqueia, possuindo formato cilíndrico e irregular. As cartilagens laríngeas (epiglote, tireóide, cricóide e aritenóidea) são interligadas e possuem formatos variados. A cartilagem tireóide demonstrou-se maior em comprimento e largura, comparativamente às demais. As cartilagens laríngeas foram submetidas a processamento histológico e coradas em hematoxilinaeosina e tricrômio de Masson. A cartilagem epiglote foi corada em azul de toluidina. As cartilagens laríngeas tireóide, cricóide e a porção inferior das aritenóides são de origem hialina; em contrapartida, a epiglote e a porção superior das aritenóides, de origem elástica. Esta última cartilagem demonstrou corpúsculos gustativos. Os resultados poderão auxiliar tanto nos atendimentos veterinários quanto nos programas de conservação desse roedor.

Palavras-chave: cartilagens laríngeas, morfologia, roedor silvestre, sistema respiratório

Recebido em 24 de agosto de 2020

Aceito em 14 de outubro de 2020

*Autor para correspondência (corresponding author)

E-mail: tsasahara@usp.br 


\section{INTRODUCTION}

The rodents belong to the order Rodentia, represented by the largest number of mammals of the Brazilian fauna, including paca (Cuniculus paca, Linnaeus 1766) family Cuniculidae (Lange and Schmidt, 2007), a wild rodent, found both in Brazilian territory and in Latin America, being typical of tropical regions (Dubost and Henry 2006; Lange and Schmidt, 2007). Pacas, due to their ideal body size, wide geographical distribution, low maintenance cost, good adaptation to new habitats and variable nutrition, have become experimental models for both human and veterinary scientific research (Martins et al., 2010). In addition, the economic exploitation of the meat cuts of paca directly favored its zootechnical importance (Santos, 2006).

Due to the diversity of rodent species, studies have investigated the larynx of chinchilla (Martinez et al., 1999), rat (Thomas et al., 2009), coati (Oliveira et al., 2012), agouti (Silva et al., 2014), capybara (Moreto et al., 2017), since there are evolutionary and functional discussions regarding the function of this organ related to the breathing, swallowing and vocalization of the animals (Harrison, 1995); however, there are no descriptions in paca.

Thus, the aim of this study was to describe the anatomical and histological aspects of the paca larynx and compare them with other domestic and wild species, given the importance of the organ and its surrounding tissues during the clinical, anesthetic and surgical care of this rodent and, for future research involving manifestations and therapies of pathological processes, in addition to the specie conservation programs.

\section{MATERIALS AND METHODS}

Eight adult pacas, males and females, with approximately $10 \mathrm{~kg}$, were donated by the Wildlife Sector facility of the Brazilian fauna for scientific purposes (Brazilian Institute of Environment and Renewable Natural Resources - IBAMA, registration number 482508) of the Faculdade de Ciências Agrárias e Veterinárias - Universidade Estadual Paulista (UNESP - Campus Jaboticabal, SP).
The animals were euthanized by previous sedation with $3 \mathrm{mg} / \mathrm{kg}$ of meperidine hydrochloride (Cristália ${ }^{\circledR}$, Itapira - SP) associated with $1 \mathrm{mg} / \mathrm{kg}$ of midazolam (Medley ${ }^{\circledR}$, Campinas - SP), both intramuscularly, in a single application. The animals were then anesthetized with $25 \mathrm{mg} / \mathrm{kg}$ ketamine hydrochloride $\left(\right.$ Vetnil $^{\circledR}$, Louveira - SP) and $0.5 \mathrm{mg} / \mathrm{kg}$ xylazine hydrochloride (Konig, Mairinque - SP) intramuscularly, in a single dose. Additionally, $19.1 \%$ intracardiac potassium chloride injection (HalexIstar Pharmaceutical Industry, Goiânia GO), dose-effect, was performed until cardiopulmonary arrest.

The animals were then fixed in $10 \%$ paraformoldehyde (Neon Comercial Ltda, São Paulo - SP) and the preservation was made in $30 \%$ saline solution (Eurofarma Laboratório S.A., Ribeirão Preto - SP). For the dissection of the laryx, the animals were positioned in dorsal recumbency and the ventral cervical region trichotomized.

After dissecting the larynges, photographic records were made with a digital camera (Canon ${ }^{\circledR}$ EOS 400D coupled with digital Sigma lens 1:1000 macro), followed by the macroscopic anatomical description as well as the topography and syntopy of the organ and its cartilages. The anatomical terms were based on the Nomina Anatomica Veterinaria (2017). Also, the laryngeal cartilages were measured using a digital caliper (Mitutoyo South America, Suzano - SP); the length $(\mathrm{mm})$ and width $(\mathrm{mm})$, by a single examiner. The larynx cartilages were sectioned in fragments and the samples fixed in $10 \%$ buffered formaldehyde (Neon Comercial Ltda, São Paulo SP, Brazil) for 24 hours and immersed into $70 \%$ alcoholic solution (Rioquímica Indústria Farmacêutica $^{\circledR}$, São José do Rio Preto - SP, Brazil) and processed according to the classical histological technique (Carson and Hladik, 2009).

According to conventional histological technique (Carson and Hladik, 2009), the sections of all laryngeal cartilages were stained in hematoxylineosin (HE) (Sigma-Aldrich, St. Louis, MO, United States) and Masson's Trichrome (MT) (Sigma-Aldrich, St. Louis, MO, United States). In addition, the epiglottis cartilage was stained in toluidine blue (Sigma-Aldrich, St. Louis, MO, United States). The slides were evaluated using a light field optical microscope (Leica 
Microsystems ${ }^{\circledR}$ DMLB, Wetzlar - Germany) as to the type of laryngeal epithelium, origins and cell types of its cartilage.

\section{RESULTS}

After a median skin incision in the ventral region of the neck, the sternohyoid, sternothyroid and omoioid muscles were folded to expose the larynx. In all cases, the larynx was located in the ventral cervical region, ventral to the esophagus and above the oropharynx with direct access to the nasopharynx, showing a cylindrical and irregular appearance, connecting the pharynx to the trachea.
The walls of the larynx are made up of extrinsic and intrinsic cartilages, ligaments and muscles, which together unite it with the hyoid bone (rostral) and the trachea (caudal).

The laryngeal cartilages are formed by three parts: epiglottic (the most rostral, forming the base of the epiglottis), thyroid (constituting the lateral walls and the floor of the larynx) and the cricoid (articulating with the thyroid and arytenoids) and a pair arytenoid (triangular shape, forming the roof of the larynx) (Figure 1).

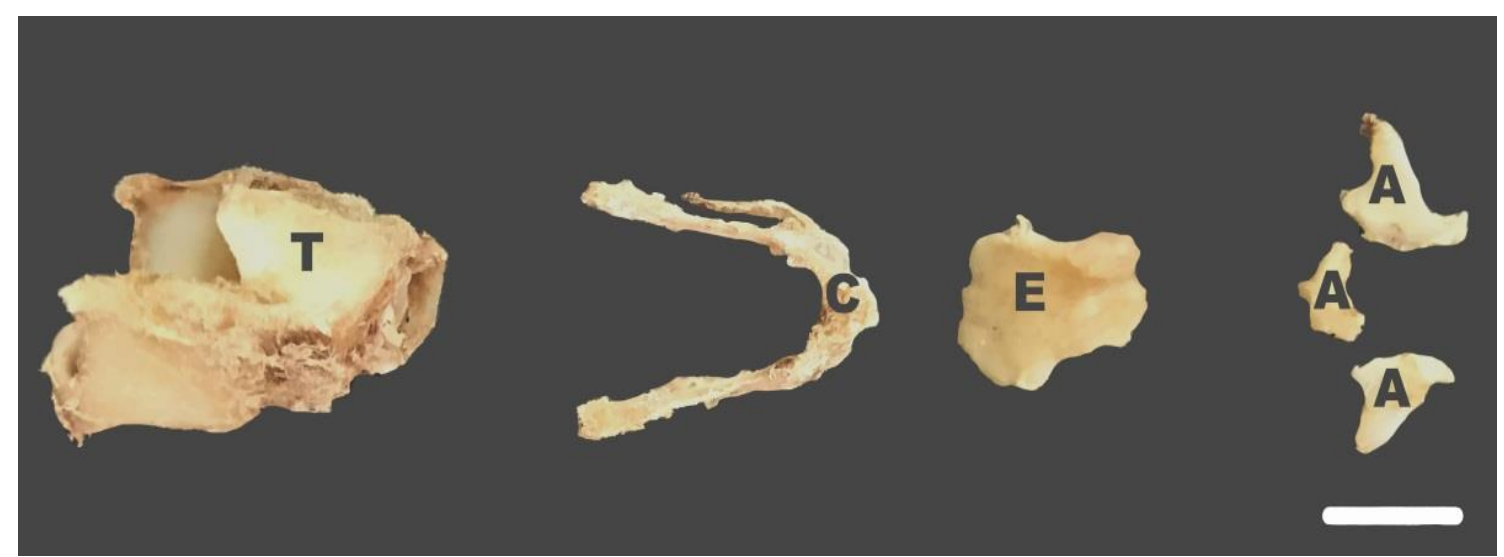

Figure 1. Photographics images of laryngeal cartilages of adult and healthy paca (Cuniculus paca, Linnaeus 1766). T: thyroid; C: cricoid; E: epiglottic and A: arytenoid.

Regarding the measurements of length and width of the laryngeal cartilages of the eight pacas, the respective means and standard deviations were obtained: epiglottic $9.49 \pm 0.69 \mathrm{~mm}$ and $7.21 \pm 0.36 \mathrm{~mm}$, thyroid $21.98 \pm 0.72 \mathrm{~mm}$ and $10.30 \pm 0.76 \mathrm{~mm}$, cricoid $5.36 \pm 0.41 \mathrm{~mm}$ and $9,43 \pm 0.42 \mathrm{~mm}$ and arytenoid $9.88 \pm 0.34 \mathrm{~mm}$ and $8.60 \pm 0.69 \mathrm{~mm}$. Histological slides showed that the larynx is a cartilaginous muscle organ, covered by stratified squamous epithelium.

The thyroid, cricoid cartilages and the lower portion of the arytenoids showed hyaline origin, with chondrocytes attached to the gaps and often forming isogenic groups. In addition, the hyaline cartilage is covered by perichondrium, with the presence of an extracellular matrix with chondroblasts and chondrocytes (Figure 2A, 2B, $2 \mathrm{C}, 2 \mathrm{D}, 2 \mathrm{E}$ and $2 \mathrm{~F}$ ). On the other hand, the epiglottis cartilage (Figure $2 \mathrm{G}$ and $2 \mathrm{H}$ ) and the upper portion of the arytenoids are composed of elastic cartilage with keratinized stratified squamous epithelium. In the epiglottis cartilage, the presence of a perichondrium was also identified, with an extracellular matrix with chondrocytes and an isogenic group. By the toluidine blue stain, it was still possible to visualize the presence of a structure suggestive of a gustatory body in the epiglottic cartilage (Figure 3). 


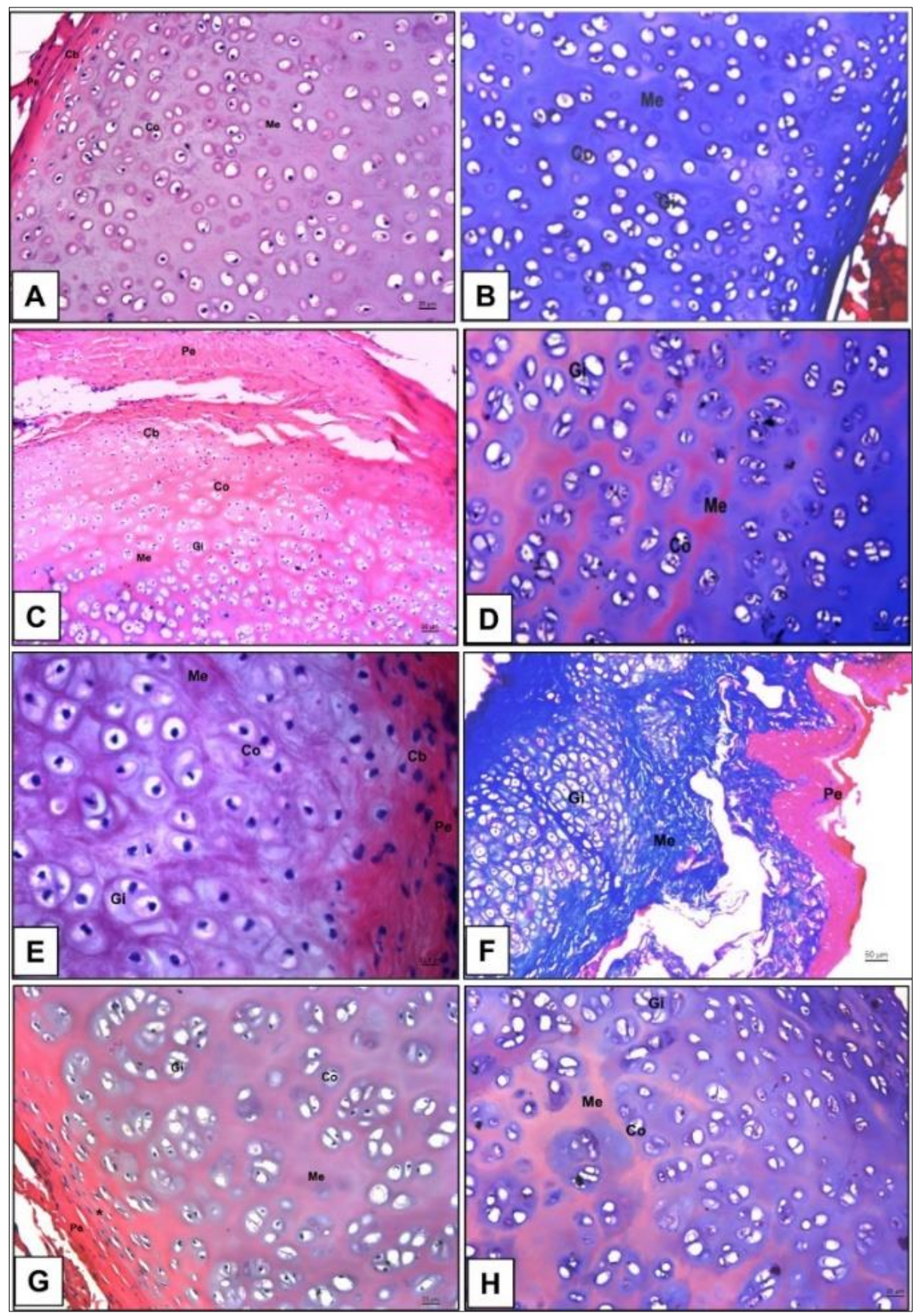

Figure 2. Photomicrographs of adult healthy paca laryngeal cartilages (Cuniculus paca, Linnaeus 1766). A and B: arytenoid cartilage, demonstrating the presence of hyaline cartilage with perichondrium $(\mathrm{Pe})$, chondroblast $(\mathrm{Cb})$, chondrocytes $(\mathrm{Co})$, extracellular matrix $(\mathrm{Me})$ and isogenic group (Gi), respectively by HE and MT stains. C and D: cricoid cartilage, showing the presence of perichondrium (Pe), chondroblast $(\mathrm{Cb})$, chondrocytes $(\mathrm{Co})$, extracellular matrix $(\mathrm{Me})$ and isogenic group (Gi), respectively by HE and MT stains. E and F: thyroid cartilage, demonstrating the presence of perichondrium $(\mathrm{Pe})$, chondroblast $(\mathrm{Cb})$, chondrocytes (Co), extracellular matrix (Me) and isogenic group (Gi), respectively by HE and MT stains. $\mathrm{G}$ and $\mathrm{H}$ : epiglottal cartilage, demonstrating the presence of perichondrium (Pe), chondrocytes $(\mathrm{Co})$, extracellular matrix (Me) and isogenic group (Gi), respectively by $\mathrm{HE}$ and $\mathrm{MT}$ stains. 


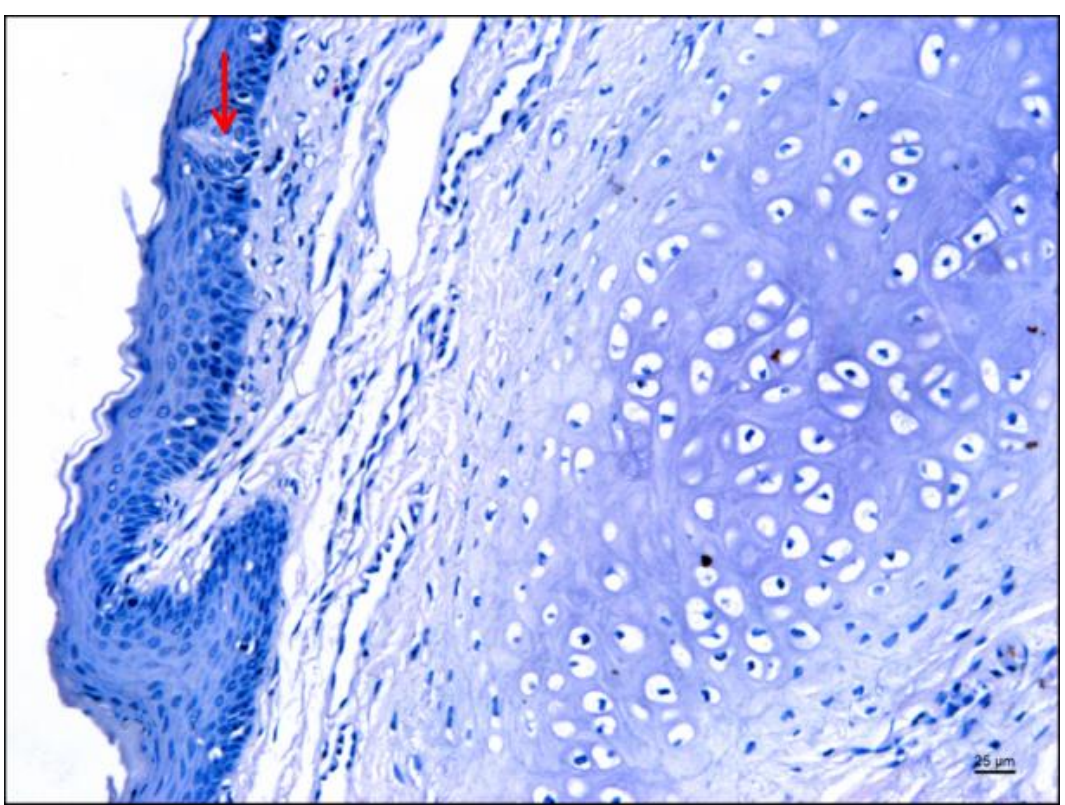

Figure 3. Photomicrograph of epiglottis cartilage of adult and healthy paca (Cuniculus paca, Linnaeus 1766), showing the presence of a taste bud (arrow). Staining: toluidine blue.

\section{DISCUSSION}

In view of the scarcity of scientific studies that describe the anatomical and histological characteristics of the paca larynx, the discussion becomes restricted. However, the descriptions regarding the morphology, topography and syntopy of the paca larynx are similar to those reported in domestic animals such as dogs, cats, horses, cattle, swine (Dyce et al., 2010; König and Liebich, 2011; Ramírez et al., 2015) and wild ones like chinchilla (Martinez et al., 1999) and agouti (Silva et al., 2014), being located in the ventral region of the neck and characterized as a short and irregular tube that connects the pharynx with the tracheobronchial tree.

According to Souza Júnior et al. (2016), the larynx of bush dogs appears on the longitudinal axis in horizontal continuity with the mandibular body, corroborating the anatomical findings found in the paca. In this sense, Saigusa (2011) stated that this is a characteristic of quadrupedal mammals. As in humans, the larynx, in animals, has a respiratory and phonatory function, preventing food from entering the airways during swallowing (Brasil et al., 2005).

The paca's larynx is formed by cartilages that articulate with each other through ligaments and muscles, as reported in domestic animals (Getty,
1986; König and Liebich, 2011) and in some rodents such as the rat (Thomas et al., 2009), coati (Oliveira et al., 2012) and capybara (Moreto et al., 2017). In this context, the epiglottis cartilage of paca was found to be the most rostral and with a rounded shape, as well as in ruminants and pigs (König and Liebich, 2011), differing from that of dogs, horses (Getty, 1986; Dyce et al., 2010) and capybaras (Moreto et al., 2017), characterized as pointed.

In all pacas analyzed, the thyroid cartilage indicated greater size, as well as in rat (Thomas et al., 2009), in coati (Oliveira et al., 2012) and in bush dog (Souza Júnior et al., 2016), consisting of a body and two lateral V-shaped blades. In contrast, in agouti, this cartilage showed little significant size compared to the cricoid and in a "U" shape (Silva et al., 2014). In this sense, the body of the paca's thyroid cartilage forms the complete base of the laryngeal tube, unlike equines, where this anatomical structure is simply composed of a narrow bridge located rostrally, on which the epiglottis is located (Getty, 1986; König and Liebich, 2011).

The paca's arytenoid cartilage, located rostrally to the cricoid, as well as in other domestic animals (Dyce et al., 2010), in the coati (Oliveira et al., 2012) and in the agouti (Silva et al., 2014), is an even structure, with an irregular pyramidal shape, 
radiating the vocal process that projects ventrally to the larynx lumen, connecting to the vocal folds, making up the glottis limit. This vocal process is also well evident in the rat and in humans (Thomas et al., 2009). The paca's cricoid cartilage is the smallest, forming the caudal end of the larynx, as in other domestic animals (Getty, 1986; König and Liebich, 2011). Also, similar to that described in the rat by Thomas et al. (2009), in agouti by Silva et al. (2014), in the bush-dog by Souza Júnior et al. (2016) and in the capybara by Moreto et al. (2017), this cartilage is located rostrally to the first tracheal ring, showing an annular shape in the paca. In addition, on the lateral and rostral borders of the cricoid cartilage of these rodents, the presence of small oval convex facets was observed for union with the thyroid and arytenoid cartilages, respectively.

Data regarding measurements of laryngeal cartilages in rodents are scarce in the scientific literature, making it impossible to discuss such parameters. In humans, the larynx is smaller in women and children (Brasil et al., 2005), as well as in most animal species, probably due to body size and the high affinity of androgen receptors in laryngeal cartilages (Harisson, 1995).

In the current research, microscopic analyzes showed that the paca's larynx is covered by stratified squamous epithelium similar with that of the chinchilla (Martinez et al., 1999) and the bush dog (Souza Júnior et al., 2016). On the other hand, Silva et al. (2014) stated that in agouti, the histological constitution of the larynx presents a diversified epithelium, depending on the region, in stratified pavement keratinized, nonkeratinized and pseudostratified ciliated with cells goblet cells.

The histological samples also confirmed that paca's thyroid, cricoid and arytenoid cartilages are of hyaline origin (providing necessary rigidity for muscle fixation that promote movement between them), while the epiglottis is elastic, similar to that reported in mammals by Kerr (2000) and Bacha Júnior and Bacha (2003), humans by Aravenda et al. (2004), in quatis by Oliveira et al. (2012), in agoutis by Silva et al. (2014) and in capybara by Moreto et al. (2017). Furthermore, microscopic analysis found that in the paca, the elastic cartilage is similar to hyaline, but in addition to the abundant amount of collagen fibers, it has a continuous elastic fiber network with those of the perichondrium (Junqueira and Carneiro, 2013).

Through the histological samples it was also possible to observe that the epithelium of the paca's epiglottis cartilage presents keratinization and a structure suggestive of gustatory corpuscle, responsible for the taste, similar to that described in carnivores, swine, ruminants (Banks, 1991), bush dog (Souza Júnior et al., 2016) and in the rostral third of the larynx of humans with stratified but not keratinized squamous epithelium (Jowett and Shrestha, 1998; Brasil et al., 2005).

\section{CONCLUSIONS}

This research elucidated basic anatomical and histological information regarding the larynx of paca (Cuniculus paca, Linnaeus 1766), aiming to assist in clinical, anesthetic, surgical, therapeutic procedures and, still, in conservation programs involving this large rodent. Thus, based on the results obtained, it is admitted that the larynx of the paca is an essential organ of the respiratory system because it connects the pharynx to the trachea, being located in the ventral region of the neck, with a cylindrical and irregular shape and constituted by the thyroid cartilages cricoid, arytenoid, hyaline in origin and epiglottis, elastic.

\section{ACKNOWLEDGEMENTS}

This work was supported by the São Paulo Research Foundation (FAPESP, Brazil; grant \# 2016/19776-7).

\section{REFERENCES}

ARAVENDA, L.D.; RICO, B.; FLORES, E. et al. Laringe canina y humana: un estudo para estabelecer homologia. Arq. Ciênc. Vet. Zool. Unipar, v.7, p.135-139, 2004.

BACHA JÚNIOR, W.; BACHA L. Atlas colorido de histologia veterinária. 2. ed. São Paulo: Roca, 2003.

BANKS, W.J. Histologia veterinária aplicada. 5.ed. São Paulo: Manole, 1991. 502 p.

BRASIL, O.O.C.; YAMASAKI, R.; LEÃO, S.H.S. Proposta de medição da posição vertical da laringe em repouso. Rev. Bras. Otorrinolaringol., v.71, p.313-317, 2005. 
CARSON, F.L.; HLADIK, C. Histotechnology a self instructional text. 3.ed. Chicago: ASCP Press, 2009. 400p.

DUBOST, G.; HENRY, O. Comparison of diets of the acouchy, agouti and paca, the three largest terrestrial rodents of French Guianan forests. $J$. Trop. Ecol., v.22, p.641-651, 2006.

DYCE, K.M.; SACK, W.O.; WENSING, C.J.G. Tratado de anatomia veterinária. 3.ed. Rio de Janeiro: Guanabara Koogan, 2010. 840p.

GETTY, R. Anatomia dos animais domésticos. 5.ed. Rio de Janeiro: Guanabara Koogan, 1986. $1001 \mathrm{p}$.

HARRISON, D.F.N. The anatomy and physiology of the mammalian larynx. Cambridge: Cambridge University Press, 1995. [288p.].

JOWEET, A.; SHRESTHA, R. Mucosa and taste buds of the human epiglottis. J. Anat., v.193, p.617-618, 1998.

JUNQUEIRA, L.C.U.; CARNEIRO, J. Histologia básica: texto e atlas. 12. ed. Rio de Janeiro: Guanabara Koogan, 2013. 538p.

KERR, J.B. Atlas de histologia funcional. São Paulo: Artes Médicas, 2000. 40p.

KÖNIG, H.E.; LIEBICH, H.G. Anatomia dos animais domésticos. 4.ed. Porto Alegre: Artmed, 2011. 824p.

LANGE, R.R.; SCHMIDT, E.M.S. Tratado de Animais Selvagens: Medicina Veterinária. São Paulo: Roca, 2007.

MARTINEZ, M.; GUIDA, H.L.; DOMINGUES, R.J.S. Morphological study of the larynx of chinchilla (Chinchilla laniger). Rev. Chil. Anat., v.17, p.39-45, 1999.

MARTINS, L.L.; OLIVEIRA, F.S.; TONIOLLO, G.H. Anestesia epidural em cutias (Dasyprocta azarae) submetidas à ovariossalpingohisterectomia. Biotemas, v.2, p.177-181, 2010.
MORETO, A.O; OLIVEIRA, F.D.; BERTASSOLI, B.M. Morfologia comparada do aparelho respiratório de capivaras (Hydrochoerus hydrochoeris). Pesq. Vet. Bras., v.37, p.267-277, 2017.

NOMINA anatomica veterinaria. 6.ed. New York: World Association of Veterinary Anatomist, 2017. 178p.

OLIVEIRA, V.C.; SOUZA, A.F.; SANTOS, A.C. Estudo morfológico do sisitema respiratório de quati (Nasua nasua). Biotemas, v.1, p.81-92, 2012.

RAMÍREZ, G.A.; ALTIMIRA, J.; VILAFRANCA, M. Cartilaginous tumors of the larynx and trachea in the dog: literature review and 10 additional cases (1995-2014). Vet. Pathol., v.52, p.1019-1026, 2015.

SAIGUSA, H. Comparative anatomy of the larynx and related structures. Japan Med. Assoc. J., v.54, p.241-247, 2011.

SANTOS, B.F. Animais de laboratório: criação e experimentação. Rio de Janeiro: Fiocruz, 2006. p.23-24.

SILVA, A.B.S.; SANTOS, T.M.V.; CARVALHO, M.A.M. Morfologia da laringe de cutia (Dasyprocta sp.). Pesq. Vet. Bras., v.34, p.593-598, 2014.

SOUZA JÚNIOR, P.; CARVALHO, N.C.; MATTOS, K. Morfologia da laringe em Cerdocyon thous (Linnaeus, 1766). Pesq. Vet. Bras., v.36, p.45-54, 2016.

THOMAS, L.B.; STEMPLE, J.C.; ANDREATTA, R.D. Establishing a new animal model for the study of laryngeal biology and disease: an anatomic study of the mouse larynx. $J$. Speech Lang. Hear. Res., v.52, p.802-881, 2009. 